\section{7 おわりに}

ニッケル水素電池のリサイクル技術開発に打いては, 想定 されたプロセスの各段階に扔いて様々な技術的な課題に直面 し，あるものは解決法を見出せたが，それが出来ずに次善の 策で済ませた部分もあった，このように，金属資源の利用・ 処理に関する技術開発では, 個々の技術課題を全て当初予定 通りに解決するのではなく, 出来る範囲まで対応した場合の 処理フロー全体の効率を評価し，それが目標を達成すれば良 しとするのが常である。これは，出発材料である天然鉱石の 性状は所与のものであり, その実態を調べることは出来ても それを人為的に改変することは出来ないという現実に対する 対応であると言える。

しかし対象がリサイクル原料（本件の場合では廃電池）の 場合，出発材料の性状は決して所与のものではない．製品の 開発や設計の段階で，部材の材質や製品の構造を選択する際 に，後日それを大量生産する際の原料入手リスクや，将来そ の使用済品をリサイクルする際の利便性までを考慮すること は，理屈としては可能なはずである，実際にそこまで配慮し て材料研究や製品開発を進める機会はなかなか無いと思われ るが，本稿では敢えてそうした検討の際の着眼点のイメージ を提供することを目指した。

具体的には，以下の点をポイントとして挙げる事が出来る，

(1) 主要材料の調達リスクという視点で見ると, 中国や南 部アフリカに供給を過度に依存しており, 供給リスク が高いレアメタルの典型であるレアアースやコバルト が不可欠なニッケル水素電池は， かなり問題の多い製 品である. タングステン, アンチモン, 白金, インジ ウムも同様の状況にあり, これらの金属はある程度の 覚悟を持って使用すべき材料だと認識されなければな らない。

（2）構成部材を物理的に選別・濃縮するには，個々の部材 が単体で分離するまで分解・破砕する必要がある。電 池のように異なる金属部材を組み合わせる場合，両者 が力学的に分離し易く, 破砕により単体分離し易い構 造であることが望ましい，その点で，円筒型のニッケ ル水素電池はリサイクルしにくい構造の典型であった 近年では角型の電池が主流になったことは, 金属りサ イクルの面からは好ましいことである.

（3）二ッケル水素電池の場合, 正極活物質は多孔質なニッ ケル中に充填されており, 負極活物質は微粉状の形態 であったことが, 破挽産物における両者の粒度の違い を生み，両者を分別する際の大きな手掛かりとなった。 性能面での要求から必然的に決まる材料の硬度, 比重,
磁性, 電気化学的性質などを, リサイクルの都合で意 罒的に変えることは難しいと思われるが，破砕した際 の粒度特性は，その部材の形状や構造を工夫すること である程度制御出来るのではないかと思われる。この 点が,「リサイクルし易い製品」を実現する上での重 要なポイントになり得る。

（4）負極活物質中に含まれる炭素化合物のように，ある機 能材料の原料中に混入するとその性能を損なうような 有機系材料が, その機能材料の成型や接着に使用され ているケースがしばしば見られる。こうした「原料と しての相性の悪い材料の組み合わせ」は，リサイクル 時の処理を一工程増やす結果となるので，極力避ける ような配慮が望まれる。

2010 年秋に中国のレアアース禁輸問題が発生する前まで は，製品開発競争の中に身を置く我が国の技術者に対し上述 のような配慮を求めても, 現実問題としては到底受け入れら れないだろうと考えていた。 しかしこの半年間で雲囲気は一 変し，今では，こうした配虑が製品開発の場で真剣に検討さ れる日がいずれ来るのではないかという気がしている.

\section{文 献}

1）経済産業省 総合資源エネルギー調查会鉱業分科会，レ アメタル確保戦略 (2009).

2）石油天然ガス・金属鉱物資源機構 金属企画調查部，鉱 物資源マテリアル・フロー2009（2010）.

3）石油天然ガス・金属鉱物資源機構 金属企画調査部, 非 鉄金属 40 鉱種のし打り (2010)

4）石油天然ガス・金属鉱物資源機構 金属資源技術部，工 ネルギー使用合理化製錬/リサイクルハイブリッドシス テムの開発事業 総括報告書・希少有価金属回収技術編 (2007)

5）石油天然ガス - 金属鉱物資源機構 金属資源技術部, 平 成 16 年度エネルギー使用合理化製錬／リサイクルハイ ブリッドシステムの開発事業 成果報告書・希少有価金 属回収技術編（2005）。

\section{著者プロフィール}

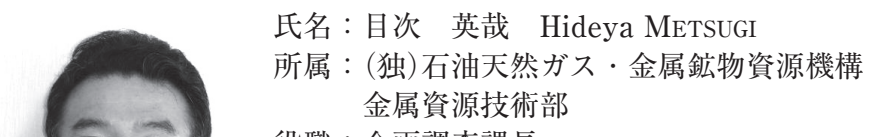

役職：企画調查課長

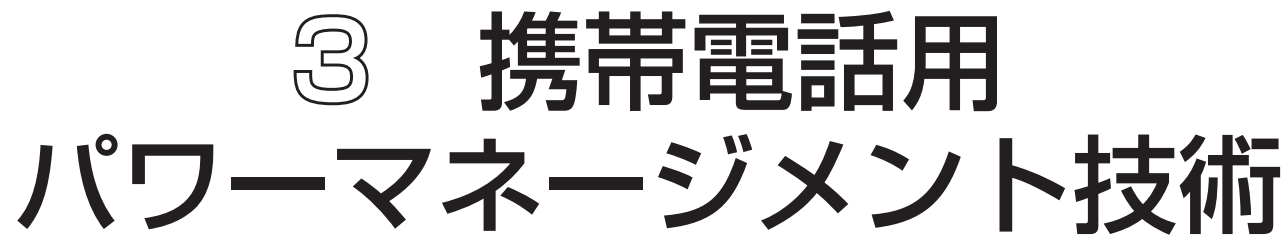

\title{
竹野 和彦
}

\section{1 はじめに}

携帯電話の消費電力は，スマートフォンへの進化や LTE
(Long Term Evolution) 方式の次世代無線通信の出現に影 響され，増加することが予想される．この対策として携带電 
話用の二次電池のエネルギー密度向上や内部電源回路の高効 率化のほかに, 充電器 (ACアダプタ) の待機電力削減など の省エ六化も実践してきた。さらに，ワイヤレス充電技術や マイクロ燃料電池技術などを用いた新しい充電技術の研究な どが盛んに行われている ${ }^{1)}$.

一方，携帯電話の電池は，使用環境がユーザに密接してい ること，あらゆる場面で使用されること，さらに運用台数の 多さなどを考慮して, 従来の家電製品以上の安全マネージメ ントが求められている. 特に, 充電や通話中の充電器の異常 温度管理や携带電話用のリチウムイオン電池の安全設計・管 理が重要視されており, リチウムイオン電池の管理（劣化・ 寿命判定）を実現するスマートバッテリーの検討なども進め られている ${ }^{2)}$.

本稿では, 携帯電話の電源系の概要, 現状の充電器 $(\mathrm{AC}$ アダプタ）の省電力化の取り組み, リチウムイオン電池の安 全性やリサイクル性を向上させるスマートバッテリー化の取 り組み，さらに新エネルギー技術（ワイヤレス充電，マイク 口燃料電池）について，その課題や方向性について述べる.

\section{2 携帯電話の電源・充電器の省電力化}

携带電話の電力の流れを Fig. 1 に示す．携带電話の電池 を充電する場合, ACアダプタ（充電器）を介して, 交流電 力を直流電力に変換し, 携带電話に入力する。 その電力は, 電池の充電制御を行う回路を介して, リチウムイオン電池パ ックに入力され，充電に使われる，さらに，電池パックから 各種電源回路を介して携带電話の内部回路に電力を供給して いる. Table 1 は携带電話に求められている各種パワーデバ イスの要求条件である ${ }^{3)}$.

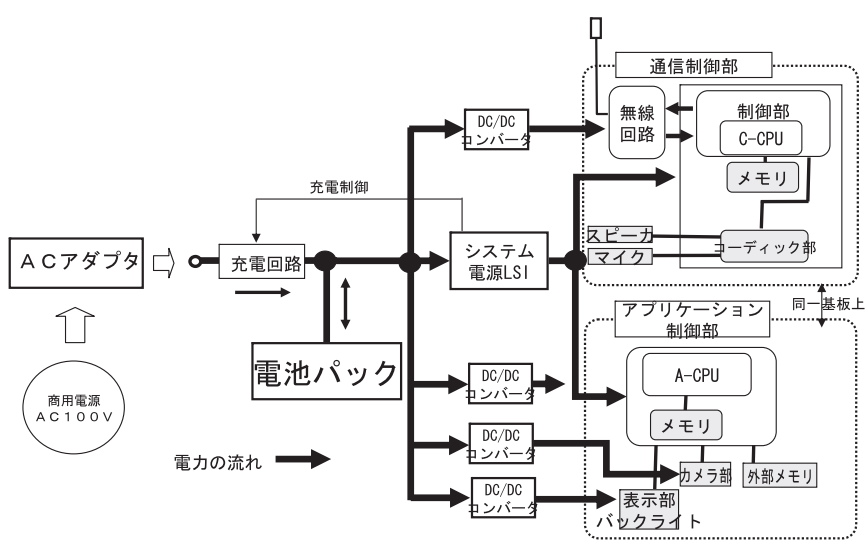

Fig. 1 携帯電話の電力系統.
ACアダプタ（充電器）に関しては，小型・軽量が主であ るが，環境対策での省電力化や利便性向上のための共通充電 器化やワイヤレス充電などの要求がある. 共通充電器化に関 しては，従来，携带電話の製造メーカ毎に充電仕様や電池仕 様が異なっていたので，個々に ACアダプタが必要であった。 しかし，ユーザの利便性の観点や重複開発の抑制の観点から， 現状の携带電話では充電仕様の共通化を行った結果，各携带 電話メーカでの共通充電器を実現している4)。さらに, 省エ ネに関する検討では，充電器を接続したままで発生する無駄 な電力である待機電力が大きな值を占めた時期があった. Fig. 2 は待機電力を削減した効果を示しており, 無負荷時 (非 充電時）の充電器内部のスイッチング電源の動作を間欠的に 制御して省エネ化した効果を示している ${ }^{3)}$

電池パックに関しては，小型・軽量化・高容量化のほかに 安全性や長寿命化である高信頼性が求められており, リチウ ムイオン電池をメインに採用してきた，今後，環境対策も求 められており，電池材料のリサイクルやCo（コバルト）な どを使わない非レアメタル化などが求められている。

携带電話内部の電源回路に関しては，現在，小型機器の制 約により電力変換回路としてリニアレギュレータが多用され ており，効率の良いスイッチング電源（DC/DC コンバータ） は一部の回路しか使われていない. Fig. 3 は携带電話の内部 電源の構成と損失を示しており，無線回路部のパワーアンプ 用電源以外では効率の低いリニアレギュレータが使われてい る.なお，現状ではパワーアンプを効率の良いスイッチング 電源化することにより, 高効率・小型化が達成されている. ただし，スイッチング電源化には，個別の電源デバイス設計 や電磁ノイズ対策が必要であり, パワーアンプ以外の回路に 展開する場合には十分な検討が必要である.

なお Fig. 4 は携带電話の待受け時間とリチウムイオン電 池のエネルギー密度の移り変わりを示している，時代毎に待 受け時間が向上しているが, これは電池容量（エネルギー密 度）の増加に寄与の他に上記の携带電話内部のパワーアンプ 部などの高効率化による寄与である ${ }^{5}$.

\section{3 リチウムイオン電池の管理技術}

前節で説明した Fig. 4 では携带電話に使用した電池の歴 史も示している. 1995 年ごろからリチウムイオン電池の搭 載が始まり, 現在（2008 年時点）において, 約 13 年間でそ のエネルギー密度が約 2 倍になっている．日本国内でも 1 億 台以上の携帯電話が運用されている現状を考えると安全性や 保守性（電池劣化・寿命評価）などの管理技術の向上が必須 である ${ }^{6-8)}$.

Table 1 携帯電話用パワーデバイスの要求条件.

\begin{tabular}{ccccc} 
対象 & 要求仕様 & 追加仕様 & $\begin{array}{c}\text { 信頼性 } \\
\text { 安全性 }\end{array}$ & 環境対策 \\
\hline AC & 小型・軽量 & 準速充電 & 長寿命 & 省電力 \\
アダプタ & 共通仕様化 & ワイレス充電 & 安全性 & リサイクル \\
& 小型, 軽量 & 薄型 & 高信頼 & 低環境物質 \\
電池 & 高容量 & 形状フリー & 高安全 & リサイクル \\
携帯電話内 & 小型 & 低ノイズ & 高実装 & 高効率 \\
電源回路 & 高効率 & 低発熱 & & \\
\hline
\end{tabular}




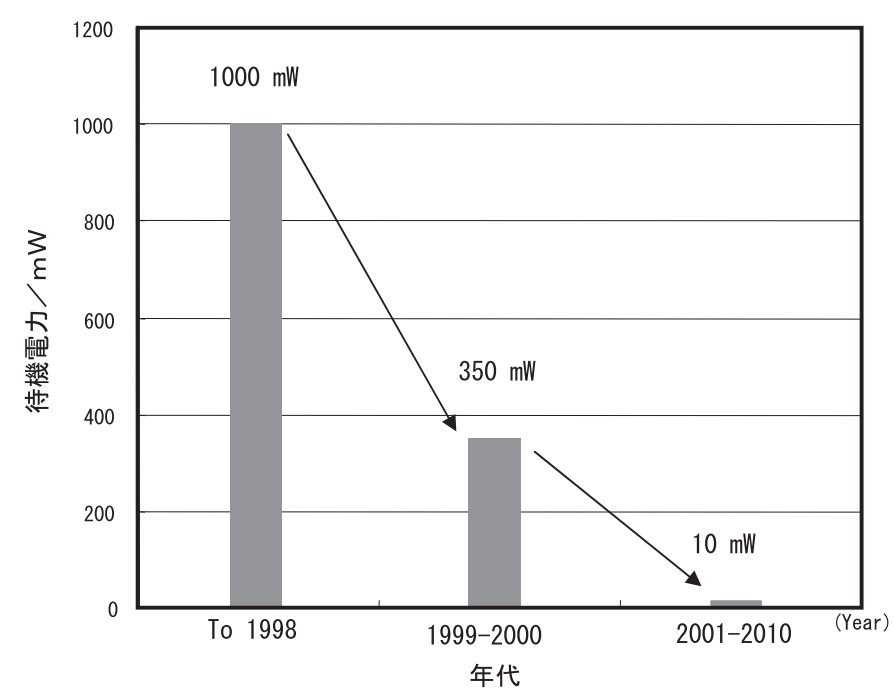

Fig. 2 低待機電力型 A Cアダプタの電力損失推移.

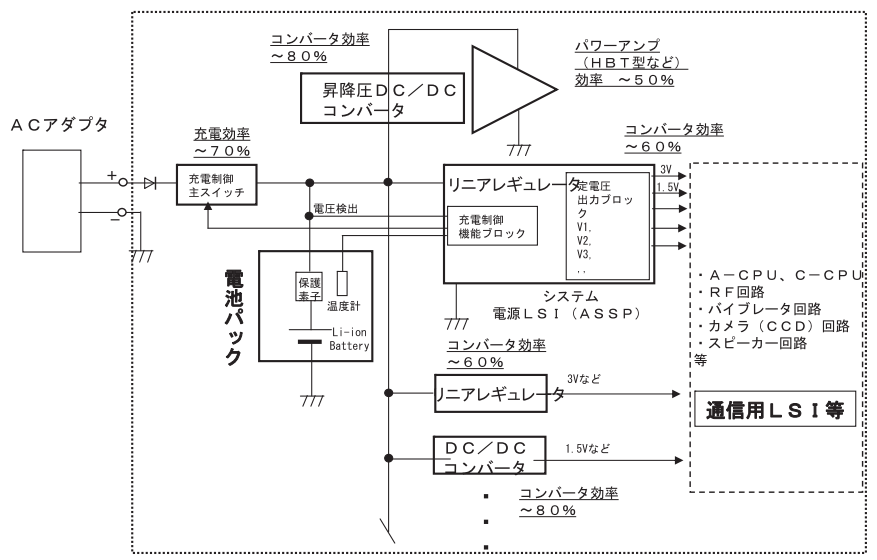

Fig. 3 携帯電話の電力損失.

安全性に関しては, Fig. 5 に示すごとく携带電話の電池パ ックでも不具合で熱暴走を起こすことがあるために ${ }^{8)}$, 電池 パックが落下や高温などの異常使用された場合でもある程度 の安全性を確保されていることが必要であり,そのための確 認試験を実施している. Table 2 は電池パックの異常使用の 想定ケースと独自に確認を実施している試験概要を示してい る. その想定されるケースに即した試験条件を設定し，過充 電, 過電圧, 圧壊試験および高温試験などを実施して安全な 電池を確認している。特に, 近年問題になっている部分的に 外部要因・内部要因で部分的に短絡が発生する事象を確認す るために, 新品や劣化品の電池を用いた部分圧壊試験を実施 している.これらの試験で問題がない電池のみ商用の携带電 話に適用している.

Fig. 6 は携带電話用に検討しているスマートバッテリーを 示している. 同図中の上左図は現行の電池パックの内部構成 であり，電池セルの他に保護回路モジュールが内蔵されてい る.このモジュールは主として過電圧や過充電を保護するの みである。同図中の上右図は検討中の電池パックを示してお り, 従来の保護機能のほかに故障診断・劣化判定機能抢よび 各種トレース機能などを追加している，特に，内部短絡を未 然に検出する機能や電池の劣化を判定する機能など電池パッ

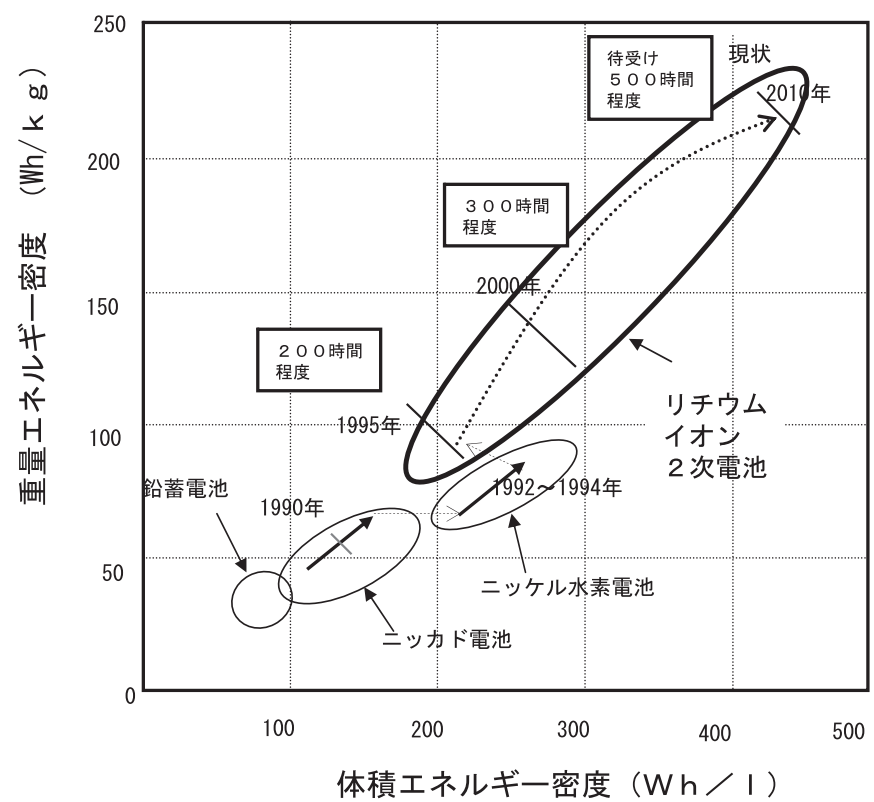

Fig. 4 待ち受け時間と電池密度.

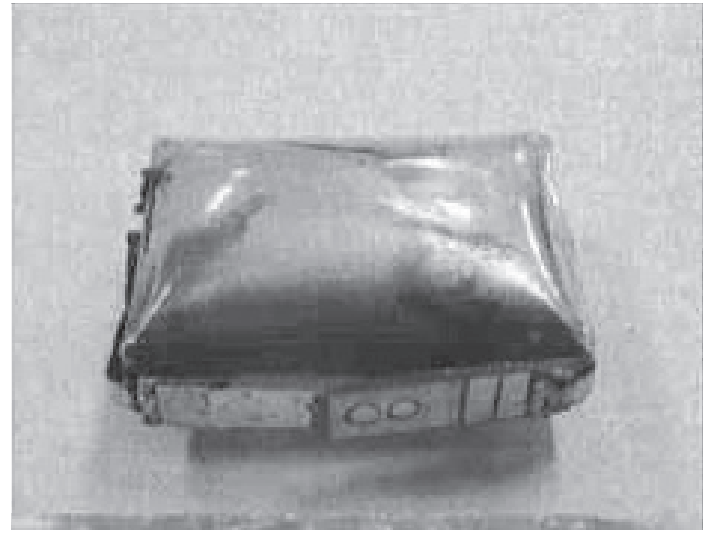

Fig. 5 熱暴走した携帯電話用リチウムイオン電池パック

クに内藏して品質向上や電池のリサイクル化などに取り組ん でいる ${ }^{9)}$.

\section{4 新エネルギー技術の展開}

携帯電話のスマートフォンへの進化などとともに電力消費 が増加することの対策として携带電話の内部回路の高効率化 や ACアダプタなどの充電器の省エネ化などを前節で解説し たが，携带電話の進化のスピードを考えると，それだけでは 省エネルギー化が達成できないことが想定される，そのため に携带電話をバイオ燃料などの再生可能エネルギーで動作さ せる新エネルギー技術に関しても検討をしている。 その中の 1 つは無線給電技術（ワイヤレス給電技術）であり ${ }^{10)}$ ，もう 1つはマイクロ燃料電池技術である ${ }^{11)}$.

ワイヤレス給電技術は, 電気的な接触で電力を送電するの ではなく, 電磁誘導, マイクロ波や可視光などのエネルギー 媒体を用いて電力を送電する技術である。 なお，電磁誘導方 式では一般家電品の非接触充電器としてすでに実用化されて いる例もあり, 防水機能を必要としかつ電力的にそんなに大 きな送電を必要としないシェーバー・電動歯磨き器（数 $100 \mathrm{~mW}$ ）などで害用化している. 現在の携帯電話に適用で 
Table 2 携帯電話用電池の安全基準.

\begin{tabular}{|c|c|c|c|}
\hline 使用環境 & 原因 & 影響 & 確認試験(ドコモ独自含) \\
\hline $\begin{array}{c}\text { 過充電 } \\
\text { (高電圧，大電流） }\end{array}$ & $\begin{array}{c}\text { 規格外充電 } \\
\text { 非純正充電器使用 }\end{array}$ & $\begin{array}{c}\text { 膨れ, 漏液, } \\
\text { 発煙, 発火など }\end{array}$ & $\begin{array}{l}\cdot \text { ·過電圧, 過充電 } \\
\text { ·DOD5 \%サイクル }\end{array}$ \\
\hline 電池端子短絡 & $\begin{array}{l}\text { 電池パック単体での } \\
\text { チェーンショートなど }\end{array}$ & $\begin{array}{l}\text { 温度上昇, } \\
\text { 漏液, 発火 }\end{array}$ & - 外部短絡試験 \\
\hline 電池破損 & $\begin{array}{l}\text { 落下, 圧壊 } \\
\text { 劣化の影響 }\end{array}$ & $\begin{array}{l}\text { 温度上昇, } \\
\text { 漏液など }\end{array}$ & $\begin{array}{l}\text { ·部分圧壊試験 } \\
\text { ·複合試験 } \\
\text { · 部分衝撃試験 }\end{array}$ \\
\hline 水濡れ & 不用意な水中投下 & $\begin{array}{l}\text { 膨れ, 充電不可 } \\
\text { (端子腐食) }\end{array}$ & $\begin{array}{l}\text { ·イオン水 } \\
\text { ·塩水水没試験 }\end{array}$ \\
\hline 高温放置 & 炎天下の車中など & $\begin{array}{l}\text { 容量劣化, } \\
\text { 膨れ, 漏液 }\end{array}$ & $\begin{array}{l}\cdot \text { 高温試験 } \\
\quad\left(150^{\circ} \mathrm{C}, 3 \text { 時間保持 }\right)\end{array}$ \\
\hline
\end{tabular}

\section{現行の電池パック}

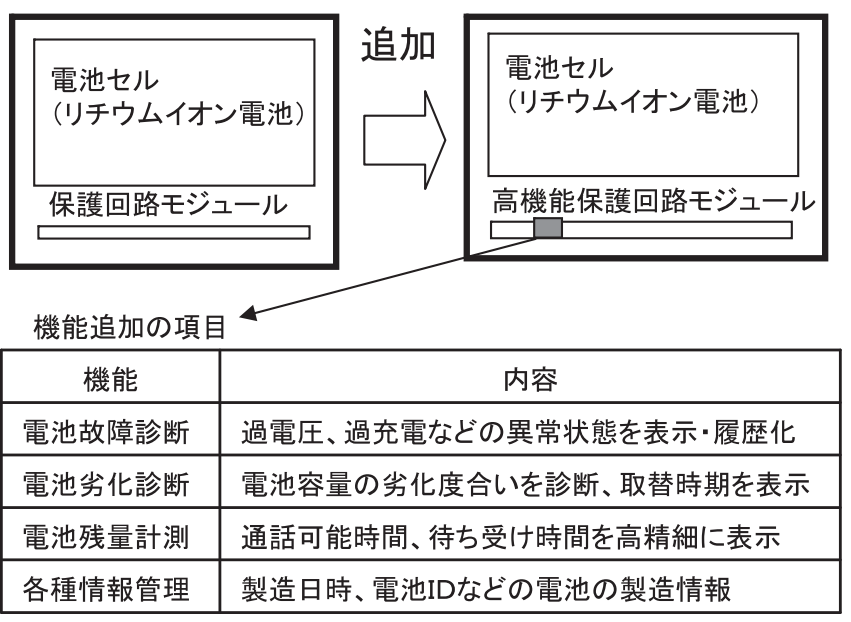

Fig. 6 携帯電話用スマートバッテリの概要.

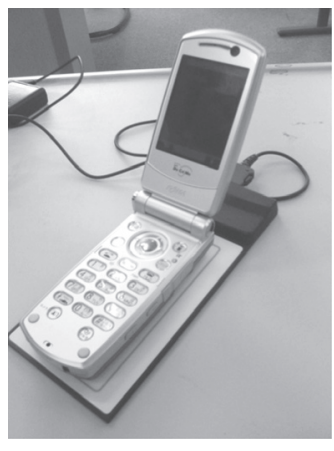

\begin{tabular}{|c|l|}
\hline 方式 & $\begin{array}{l}\text { 磁気結合型コイルによる } \\
\text { 電カ送電方式 }\end{array}$ \\
\hline サイズ $(\mathrm{mm})$ & $\begin{array}{l}151 \times 70 \times 11 \text { (置き台部) } \\
55 \times 31 \times 5 \text { (電池蓋部) }\end{array}$ \\
\hline 電気入カ & $\begin{array}{l}5.4 \mathrm{~V}, 700 \mathrm{~mA} \\
\text { (FOMA共通ACアダプタ使用) }\end{array}$ \\
\hline 電気出カ & $5.5 \mathrm{~V}, 400 \mathrm{~mA}$ (電池蓋端) \\
\hline 充電時間 & $\begin{array}{l}\text { 約120分 (P901i用電 } \\
\text { 池を充電した場合の例) }\end{array}$ \\
\hline
\end{tabular}

Fig. 7 携带電話用ワイヤレス充電器.

きればコネクタレスが可能になり，防水・小型化および専用 の充電器レスなどに貢献できる. Fig. 7 は電磁誘導方式を用 いて携帯電話（約 $3 \mathrm{~W}$ ）に適用した例である ${ }^{12}$ ． 本方式は 一次側および二次側コイルともにスパイラル・インダクタ （コイル）を用いて薄型化し，一次側の置き台には制御回路 とコイルを内蔵して一体化させている。 二次側コイルの配置 場所は, 電池蓋に内蔵する方式を採用している. 電池蓋に二 次側コイルと交流電力を整流する整流回路を内蔵化すること により，電池蓋以外の携帯電話本体を極力変更しない構成を

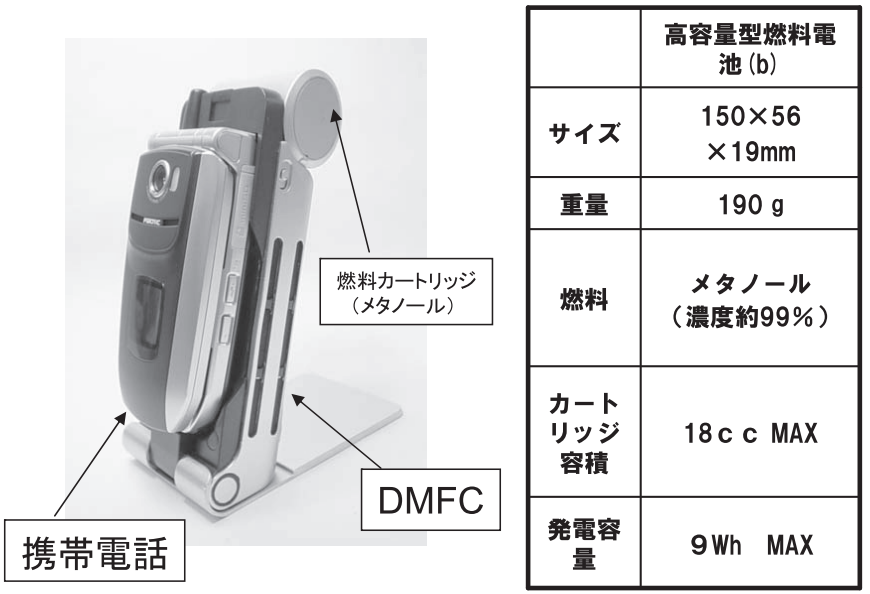

Fig. 8 携帯電話用 DMFC 充電器.

実現している，今後，一次側の置き台をいろいろな場所に設 置して, いつでもどこでも充電できる充電インフラを構築し, 電池容量不足の解消などを図っていく.

マイクロ燃料電池技術は, リン酸型 $(\mathrm{PAFC})$, 固体電解 質型 (SOFC) および固体高分子型 (PEFC) などのいろい ろな燃料電池の種類の中で, 携带電話に適用する燃料電池と して, 動作温度や燃料の種類や構造の簡易性より, PEFC 型 および PEFC 型の一種であるメタノール直接型（DMFC） の燃料電池が有力であり，検討を行っている．携帯電話向け に開発した DMFC 型の燃料電池を Fig. 8 示す. 本燃料電池 は合体型（クレドル型）の試作機であり，99\%以上の高濃 度メタノール燃料を $18 \mathrm{cc}$ 入れた燃料カートリッジを接続し て発電を行なっている. 本試作機を携帯電話に合体させて通 話を行なった場合, 携帯電話の内蔵電池と合算して, 約 8 時 間の連続通話が可能となり, 携帯電話の安定動作に貢献する ことが可能となっている. 今後, 燃料電池用の燃料のバイオ 化（バイオメタノール）などの採用によりいっそうの環境負 荷軽減なども図っていく予定である ${ }^{13)}$.

\section{5 おわりに}

本稿では, 携帯電話に代表されるモバイル機器向け電池・ 電源の省エネ化などについて述べてきた. 主として携帯電話 の内部電源や充電機の動向や, リチウムイオン電池の運用上 の課題や管理方法の検討を述べ，特に安全性に関する確認が 
必要であることを示した．また，燃料電池などの新エネルギ 一技術の必要性も述べた。

今後, 次世代の携带電話や PDA などに代表されるような モバイル機器の発展が期待されている. その電源に必要な次 世代電源技術の動向や安全性を確認しながら, 環境負荷の少 ない携帯電話に適した電池や充電器などの開発・商品化を推 進していく.

\section{文 献}

1）竹野和彦, 日経コミュニケーション，4.15 号 p.54 (2009).

2）竹野和彦, 松岡保静, 信学技報, 110 (393), EE2010-36, p.49 (2011).

3) K. Takeno, M. Ichimura, K. Takano, and J. Yamaki, Proceeding of Intelec 03, p.310 (2003).

4）竹野和彦, NTT DoCoMo テクニカルジャーナル, 16 (2), p.35 (2008).

5）岡田 隆, NTT DoCoMoテクニカルジャーナル, 16 (2), p.45 (2008).

6) 竹野和彦, 興梠英規, NTT DoCoMo テクニカルジャー ナル, 10 (2), p.42 (2002).

7) K. Takeno, M. Ichimura, K. Takano, and J. Yamaki, J.
Power Sources, 142, 298 (2005).

8）竹野和彦, 山木準一, 電子情報通信学会論文誌 $\mathrm{B}$, J93-B, p.1296 (2010).

9) 竹野和彦, 日経コミュニケーション, 4.1 号 p.78 (2009).

10）竹野和彦, ワイヤレス充電 2010 , 日経 BP 社, p.32 (2010).

11）竹野和彦, 携带電話キーデバイスの開発と最新動向, CMC 出版, p.200 (2007).

12）竹野和彦，上村治雄，信学技報， 110 (65), EE2010-5, p.31 (2010).

13）金村聖志, 杉山憲次, 棟方裕一, 竹野和彦, 栗田修二, 長谷川理, 第 51 回電池討論会予稿集, $1 \mathrm{E} 25$, p.325 (2010).

\section{○著者プロフィール}

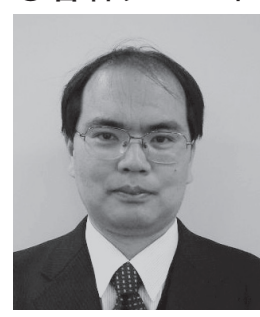
所属：NTT ドコモ先進技術研究所環境技術 研究グループ

役職: 主幹研究員

趣味：ドライブ 